\title{
Defensive properties of pyrrolizidine alkaloids against microorganisms
}

\author{
Lotte Joosten · Johannes A. van Veen
}

Received: 29 January 2010/ Accepted: 4 November 2010/Published online: 23 November 2010

(C) The Author(s) 2010. This article is published with open access at Springerlink.com

\begin{abstract}
The understanding of the selection factors that drive chemical diversification of secondary metabolites of constitutive defence systems in plants, such as pyrrolizidine alkaloids (PAs), is still incomplete. Historically, plants always have been confronted with microorganisms. Long before herbivores existed on this planet, plants had to cope with microbial pathogens. Therefore, plant pathogenic microorganisms may have played an important role in the early evolution of the secondary metabolite diversity. In this review, we discuss the impact that plant-produced PAs have on plant-associated microorganisms. The objective of the review is to present the current knowledge on PAs with respect to antimicrobial activities, adaptation and detoxification by microorganisms, pathogenic fungi, root protection and PA induction. Many in vitro experiments showed effects of PAs on microorganisms. These results point to the potential of microorganisms to be important for
\end{abstract}

L. Joosten - J. A. van Veen

Plant Ecology and Phytochemistry, Institute of Biology, Leiden University, P.O. Box 9505, 2300 RA Leiden, The Netherlands

e-mail: h.vanveen@nioo.knaw.nl

L. Joosten $(\bowtie) \cdot$ J. A. van Veen

Microbial Ecology, Netherlands Institute of Ecology, P.O. Box 40, 6666 ZG Heteren, The Netherlands e-mail: L.Joosten@biology.leidenuniv.nl

J. A. van Veen

P.O. Box 9505, 2300 RA Leiden, The Netherlands the evolution of PAs. However, only a few in vivo studies have been published and support the results of the in vitro studies. In conclusion, the topics pointed out in this review need further exploration by carrying out ecological experiments and field studies.

Keywords Anti-microbial activity - Adaptation · Pathogens $\cdot$ Plant defence $\cdot$ Secondary metabolites
Abbreviations
$N \quad$ Nitrogen
PAs Pyrrolizidine alkaloids

\section{Introduction}

Many plants synthesize a range of diverse secondary metabolites that are toxic and/or deterrent for herbivores and pathogens. This diversity might be one of the strategies that plants use in order to defend themselves against the great variety of potential environmental threats. Species of several families within the angiosperms are known for their production of nitrogen-based secondary metabolites called pyrrolizidine alkaloids (PAs). PAs have toxic, deterrent and/or repellent effects on a wide range of generalist herbivores in order to reduce or prevent damage (van Dam et al. 1995; Hartmann 1999; Hartmann and Ober 2000; Ober 2003). Our understanding of the selection 
factors that drive chemical diversification of PAs in plants is still incomplete. It has been suggested that the diversity of PAs in plant species have evolved under selective pressures by generalist herbivores (Hartmann and Dierich 1998; Macel et al. 2005). However, long before herbivores existed, plants already had to cope with the attack of microorganisms. Therefore, we suggest that also microbial pathogens played an important role in the evolution of the secondary metabolite diversity. If so there should be differences in effectiveness of the individual PA types against microorganisms as well as differences in adaptation of microorganisms to the different PAs.

In this review we will discuss the current knowledge on the anti-microbial activities of PAs and the ecological consequences of this activity. More specifically we will ask; (1) Do PAs show anti-microbial activities in in vitro tests; (2) Do microorganisms adapt to PAs? (3) Do PAs have an effect on aboveground pathogenic fungi?; (4) Do PAs play a role in root protection against soil-borne microorganisms?; (5) Is the PA defence system inducible by microorganisms?

\section{Ecologically relevant in vitro anti-microbial activity of alkaloids}

A Web of Science search for "+Topic $=($ alkaloid* $)$ AND Topic $=($ microorganism* $)$ AND Topic $=$ (plant*) Timespan $=$ All Years" throws back 153 hits while when replacing "Topic $=($ microorganism* $)$ " for "Topic $=$ (insect*)" 602 hits are shown. This already indicates that more attention is paid to the effects of PAs on insect herbivores. In addition, most studies on the anti-microbial activities of alkaloids have pharmaceutical purposes, deal with PA toxicity in mammals or based on PAs not produced by plants.

Nevertheless, toxic anti-bacterial or anti-fungal activities of plant alkaloids have been shown in a number of studies. Recently Erdemoglu et al. (2007, 2009) reported that quinolizidine alkaloid extracts (inhibitory concentrations of $62.2-500 \mu \mathrm{g} / \mathrm{ml}$ ) from the aerial parts of Lupinus angustifolius and Genista vuralii showed activity against several different bacterial species. Anti-fungal effects by alkaloids also have been found for several plant associated fungi by bioassay experiments (Wippich and Wink 1985; Zhao et al. 1998; Ma et al. 1999; Zhou et al. 2003). In the study by Wippich and Wink's (1985), several quinolizidine alkaloids were mentioned that inhibited the germination of conidia Erysiphe graminis. Zhao et al. (1998) reported that two furoquinoline alkaloids showed activity against the phytopathogenic fungus Cladosporium cumcumerinum. The inhibitory concentrations of the two alkaloids, dictamnine and haplopine, was $25 \mu \mathrm{g} / \mathrm{ml}$ and originated from root bark of Dictamnus dasycarpus. Ma et al. (1999) showed that the isoquinoline alkaloids, corynoline and acetylcorynoline, inhibited the fungal growth of Cladosporium herbarum at a concentration of $3 \mu \mathrm{g} / \mathrm{ml}$. Zhou et al. (2003) reported that steroidal alkaloids from the rhizomes and roots of Veratrum taliense inhibited the growth of the phytopathogenic fungi, Phytophthora capisis and Rhizoctonia cerealis in concentrations of 80-200 $\mu \mathrm{g} / \mathrm{ml}$.

The role that PAs (as a specific group of alkaloids) play in plant protection against microorganisms is still rather unclear. A Web of Science search for "Topic = (pyrrolizidine) AND Topic $=($ microorganism* $\mathrm{OR}$ fung* OR bacteri*) AND Topic $=($ plant*) Timespan $=$ All Years" throws back 81 hits. Around 75\% of all studies on the anti-microbial activities of PAs, are not related to plant defence. When replacing "Topic $=$ (microorganism* OR fung* OR bacteri* ${ }^{*}$ " by "Topic $=($ insect*)", than 162 hits are shown.

Table 1 shows an overview of studies on PA effects on the growth of microorganisms. From a total of 43 bioassay-tests with different bacterial species 65\% showed a negative sensitivity to the different PAs (Jain and Sharma 1987; Marquina et al. 1989; Singh et al. 2002). Anti-bacterial effects of PAs produced by Heliotropium species were investigated in a few in vitro studies (Jain and Sharma 1987; Marquina et al. 1989; Singh et al. 2002). In these studies the growth of bacterial species, mostly human pathogens, such as E. coli, Streptococcus pneumoniae, B. subtilis, Bacillus anthracis and S. aureus, was inhibited in the presence of different pure PAs and PA plant extracts (see Table 1).

More is known about the effect of PAs on fungi. Also here most studies were carried out in vitro. Of the 145 bioassay-tests with different fungal species, $61 \%$ showed significant growth inhibition caused by the different PAs (Jain and Sharma 1987; Marquina et al. 1989; Reina et al. 1995, 1997, 1998; Singh et al. 2002; Hol and van Veen 2002; Hol et al. 2003). Early 
Table 1 Overview of studies on pyrrolizidine alkaloids and the effect on the growth of microorganisms. PAs studied showed a significant negative effect on at least one of the microorganisms tested and visa versa

\begin{tabular}{|c|c|c|c|c|}
\hline Pyrrolizidine alkaloids & Alkaloid origin & Microorganisms & $\begin{array}{l}\text { Inhibition concentration } \\
(\mathrm{mg} / \mathrm{ml})\end{array}$ & References \\
\hline $\begin{array}{l}\text { Europine } \\
\text { Heliotridine } \\
\text { Lasiocarpine }\end{array}$ & $\begin{array}{l}\text { Aerial parts } \\
\text { Heliotropium } \\
\text { ellipticum }\end{array}$ & $\begin{array}{l}\text { Bacteria } \\
\text { Escherichia coli } \\
\text { Streptococcus } \\
\quad \text { pneumoniae }\end{array}$ & $\begin{array}{l}\text { Bacterial and fungal growth } \\
100\end{array}$ & $\begin{array}{l}\text { Jain and Sharma } \\
\text { (1987) }\end{array}$ \\
\hline $\begin{array}{l}\text { Lasiocarpine } N \text {-oxide } \\
\text { PA extract }\end{array}$ & & $\begin{array}{l}\text { Bacillus subtilis } \\
\text { Bacillus anthracis } \\
\text { Staphylococcus aureus } \\
\text { Fungi } \\
\text { Candida albicans } \\
\text { Curvularia lunata } \\
\text { Phytopathogenic fungi } \\
\text { Drechslera tetramera } \\
\text { Aspergillus flavus } \\
\text { Fusarium moniliforme }\end{array}$ & & \\
\hline $\begin{array}{l}\text { 9-Angeloylretronecine } \\
N \text {-oxide }\end{array}$ & Aerial parts & Bacteria & Bacterial and fungal growth & $\begin{array}{l}\text { Marquina et al. } \\
\text { (1989) }\end{array}$ \\
\hline $\begin{array}{l}\text { Supinine } \\
\text { Heliotrine (no sign. effect) } \\
\text { Lasiocarpine } \\
\text { PA extract }\end{array}$ & $\begin{array}{l}\text { Heliotropium } \\
\text { bursiferum }\end{array}$ & $\begin{array}{l}\text { Bacillus subtilis } \\
\text { Phytopathogenic fungi } \\
\text { Candida tropicalis } \\
\text { Aspergillus niger }\end{array}$ & 50 & \\
\hline $\begin{array}{l}\text { Europine } \\
\text { 7-acethyleuropine (no sign. } \\
\text { effect) }\end{array}$ & $\begin{array}{l}\text { Aerial parts } \\
\text { Heliotropium bovei }\end{array}$ & $\begin{array}{l}\text { Phytopathogenic fungi } \\
\text { Fusarium moniliforme }\end{array}$ & $\begin{array}{l}\text { Fungal growth } \\
0.01-0.25\end{array}$ & Reina et al. (1995) \\
\hline $\begin{array}{l}3^{\prime} \text {-Acetyltrachelanthamine } \\
\text { Floridinine } \\
\text { PA extract } \\
\text { Plant extract }\end{array}$ & $\begin{array}{l}\text { Aerial parts } \\
\text { Heliotropium floridum }\end{array}$ & $\begin{array}{l}\text { Phytopathogenic fungi } \\
\text { Fusarium oxysporum } \\
\text { Fusarium moniliforme } \\
\text { Fusarium avenaceum } \\
\text { Fusarium solani }\end{array}$ & $\begin{array}{l}\text { Fungal growth } \\
0.5\end{array}$ & Reina et al. (1997) \\
\hline $\begin{array}{l}\text { Megalanthonine (no sign. } \\
\text { effect) }\end{array}$ & Aerial parts & Phytopathogenic fungi & Fungal growth & Reina et al. (1998) \\
\hline Lycopsamine (no sign. effect) & $\begin{array}{l}\text { Heliotropium } \\
\text { megalanthum }\end{array}$ & Fusarium moniliforme & 0.5 & \\
\hline $\begin{array}{l}\text { Subulacine } N \text {-oxide } \\
\text { 7-Angeloyl heliotrine } \\
\text { Retronecine }\end{array}$ & $\begin{array}{l}\text { Aerial parts } \\
\text { Heliotropium } \\
\text { subulatum }\end{array}$ & $\begin{array}{l}\text { Bacteria } \\
\text { Escherichia coli } \\
\text { Streptococcus } \\
\quad \text { pneumoniae }\end{array}$ & $\begin{array}{l}\text { Bacterial and Fungal growth } \\
2 \mathrm{mg} / \mathrm{disk}\end{array}$ & Singh et al. (2002) \\
\hline Heliotrine & & $\begin{array}{l}\text { Bacillus subtilis } \\
\text { Bacillus anthracis } \\
\text { Staphylococcus aureus } \\
\text { Phytopathogenic fungi } \\
\text { Aspergillus fumigatus } \\
\text { Aspergillus niger } \\
\text { Rhizoctonia phaseoli } \\
\text { Penicillium } \\
\text { chrysogenum }\end{array}$ & & \\
\hline
\end{tabular}


Table 1 continued

\begin{tabular}{|c|c|c|c|c|}
\hline Pyrrolizidine alkaloids & Alkaloid origin & Microorganisms & $\begin{array}{l}\text { Inhibition concentration } \\
(\mathrm{mg} / \mathrm{ml})\end{array}$ & References \\
\hline Monocrotaline & Aerial parts & Phytopathogenic fungi & Fungal growth & \multirow{4}{*}{$\begin{array}{l}\text { Hol and van Veen } \\
\text { (2002) }\end{array}$} \\
\hline Retrorsine & Jacobaea vulgaris & Fusarium oxysporum & $0.01-1.08$ & \\
\hline Retrorsine $N$-oxide & & Fusarium sambucinum & & \\
\hline PA extract & & Trichoderma sp. & & \\
\hline Monocrotaline & Aerial parts & Phytopathogenic fungi & Fungal growth & \multirow[t]{10}{*}{ Hol (2003) } \\
\hline Senecionine & $\begin{array}{l}\text { Senecio } \\
\quad \text { brasiliensis }\end{array}$ & Fusarium oxysporum & $0.01-1.08$ & \\
\hline Retrorsine & \multirow[t]{8}{*}{ Jacobaea vulgaris } & Fusarium sambucinum & & \\
\hline Integerrimine & & Mortierella sp. & & \\
\hline Integerrimine + Retrorsine & & Minimedusa sp. & & \\
\hline $\begin{array}{l}\text { Bulk extract Jacobaea } \\
\text { vulgaris }\end{array}$ & & $\begin{array}{l}\text { Plectosphearella } \\
\text { cucumerina }\end{array}$ & & \\
\hline & & Rhizoctonia sp. & & \\
\hline & & Broomella acuta & & \\
\hline & & Pestalotiopsis sp. & & \\
\hline & & Trichoderma sp. & & \\
\hline
\end{tabular}

work of Jain and Sharma (1987) and Marquina et al. (1989) reported anti-yeast and anti-fungal activities (see Table 1). Reina et al. (1995) found anti-fungal activity against Fusarium moniliferme by the PA europine produced by Heliotropium bovei. PAs produced by Heliotropium subulatum showed to be active against Aspergillus fumigatus, Aspergillus niger, Rhizoctonia phaseoli and Penicillium chrysogenum (Singh et al. 2002).

PAs from Heliotropium species are open chain diesters and differ in structure from the PAs in Senecio and Jacobaea species, which are macrocyclic diesters (see Fig. 1). Hol and van Veen (2002) investigated the growth-reducing effects of PAs from Jacobaea vulgaris on different plant-associated fungi. The growth of five soil fungal strains of Fusarium oxysporum, Fusarium sambucinum and Trichoderma sp. was temporarily inhibited by different purified PAs among which monocrotaline, retrorsine, retrorsine $\mathrm{N}$-oxide and PA plant extract. The concentrations 0.33 and $3.33 \mathrm{mM}$ (equal to ca. 0.1 and $1.08 \mathrm{mg} / \mathrm{ml}$ used in in vitro tests), at which the most inhibitory effects were found, are comparable to PA concentrations (0.3-3 mM fresh weight) found in plant tissue under natural conditions for J. vulgaris (Hol et al. 2003; Kowalchuk et al. 2006). PA plant extracts from $J$. vulgaris, containing a bouquet of different PAs, was the most active inhibitor. The tested PAs never stopped fungal growth totally. After initial growth-delay the fungi were able to adapt and to grow normally within 30 days. Hol and van Veen (2002) hypothesized that the observed temporary mycelium growth-delay may have serious ecological consequences for the affected fungi, as it may impact the competition between microorganisms in the rhizosphere and will give plant roots extra time to raise its defences or escape (Hol and van Veen 2002). Mycelium growth was not in all cases negatively influenced by the PA treatments but depended on where a particular fungal line originated from. The potential adaptation of isolated fungi from PA-producing plants will be further discussed below.

Based on the published literature the majority of in vitro studies showed a negative effect of PAs on microorganisms. Although results of in vitro studies cannot be translated easily to ecologically relevant conditions, these studies indicate that PAs can play an important role in the defence against microorganisms in natural systems.

\section{Adaptation by microorganisms to alkaloids}

The diversity in plant defence compounds is thought to result from the arms race between the plant and its attacker (Ehrlich and Raven 1964). This biochemical 
Fig. 1 Effective chemical structures of pyrrolizidine alkaloids against microorganisms mentioned in this manuscript

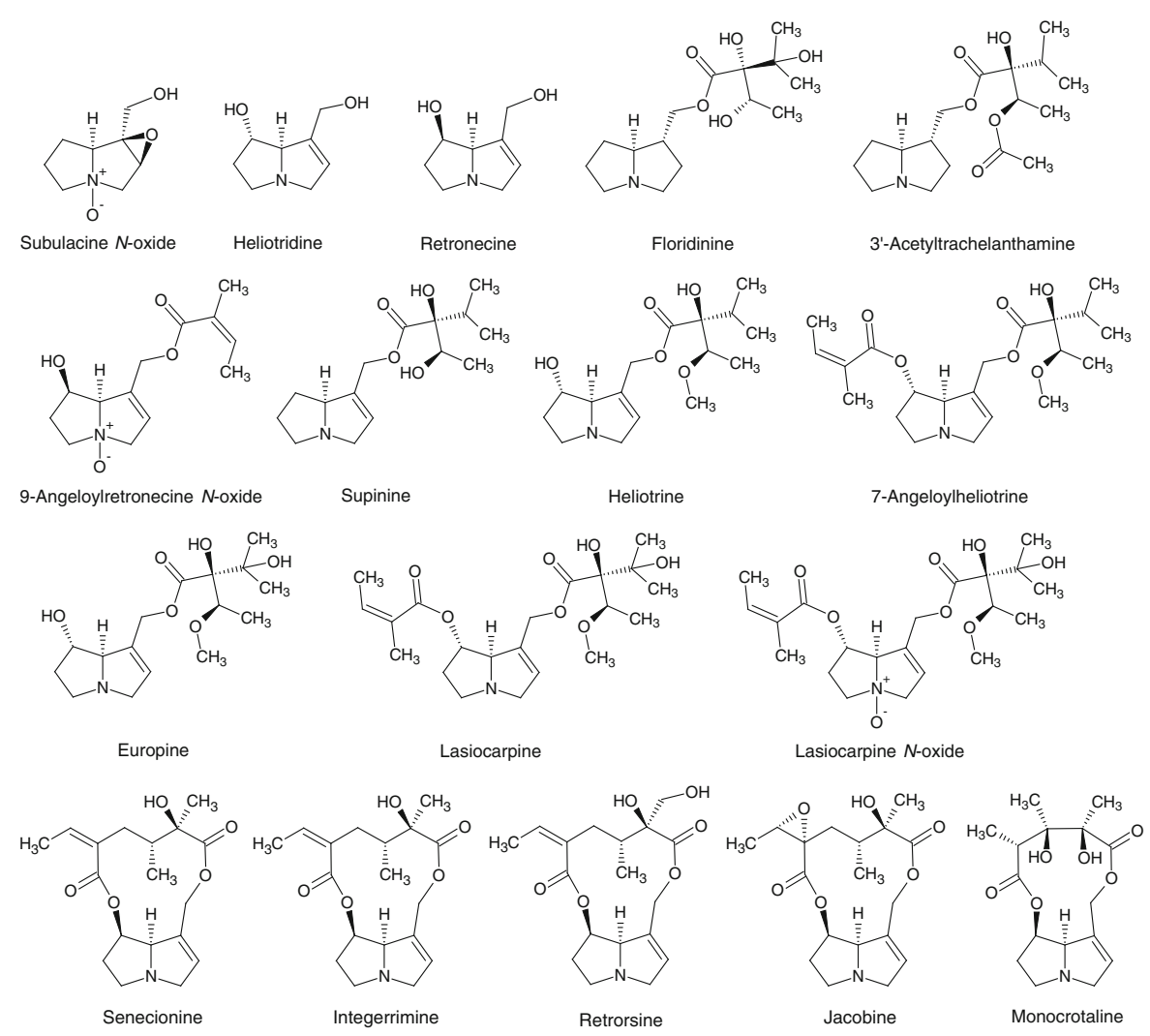

co-evolutionary theory assumes that, in response to adaptation by the attacker, plants need to synthesize new defence compounds by modification of the original compound. Crucial in this hypothesis is the ability of the attackers to adapt to defence compounds. For insects it has been shown that indeed they can (Lindigkeit et al. 1997). For microorganisms the evidence is less clear. However, given their short generation time and the extremely high numbers of individuals one might expect an even higher ability to adapt to chemical defence compounds. In addition it has been suggested (Hol 2003) that microbial pathogens may be stronger selective agents than herbivore attackers because they are more likely to kill hosts in contract to herbivores, which often abandon there host after defoliation. Although potentially an interesting hypothesis, the evidence to support this is weak.

Adaptation is known in microbiology as a development of resistance. Many resistance mechanisms are known, such as making it more difficult for the toxin to enter the microorganism, and chemical modification of the toxic compound which results in inactivation of the toxin. Adaptation by fungi to secondary metabolites is known for a variety of compounds such as steroidal glycoalkaloids (Osbourn 1996; Morrissey and Osbourn 1999) and phytoalexins (Soby et al. 1996). Adaptation by inactivating the toxin could be followed by the ability to utilize the compounds as substrate for energy and biomass production or storage for their own defence against attackers (McGonigle and Hyakumachi 2001). Endophytic symbionts, for instance, need to cope with the secondary metabolites of their host plant, like Rhizobium specimens. They form symbioses with members of the leguminoseae, such as lupines, which produce large amounts of alkaloids, in particular, quinolizidine alkaloids (Wink 1988; Harborne 2003). Werner et al. (1997) showed that endophytic fungi were able to metabolize the polyamine alkaloid aphelandrine. Several fungi were capable to use part of the polyamine alkaloid as nitrogen source. Nearly all fast-growing endophytes of the family of Nectriaceae were able to degrade and to grow on this alkaloid while slow-growing endophytes could only partially degrade aphelandrine. 
A study by Hol and van Veen (2002) showed that there is a remarkable difference in fungal sensitivity in relation to the host plant. Five $F$. oxysporum lines, isolated from different host plants $(2 \times J$. vulgaris, Carex arenaria, Senecio vulgaris and unknown host plant) were stimulated by the PA bulk treatments. The stimulation of some isolates by the PA bulk suggests that adaptation may have taken place (Hol and van Veen 2002). Hol (2003) showed that fungi isolated from $J$. vulgaris roots were initially inhibited but, later, their growth was stimulated by different concentrations of a bulk PA mix extracted from the plant. This suggests that adaptation took place. They suspected that the increased growth could be the result of the ability to use PAs as nutrition. In these experiments $75 \%$ of the nitrogen was present in the form of PAs (Hol 2003). However, the idea that PAs are used as nutrition is merely an assumption because the study was not targeted at finding direct evidence that fungi were able to metabolize and use PAs as a source of nitrogen. It would be very interesting to test if the fungi actually inactivate PAs and utilises PAs for further growth. Three fungi, which were sensitive to retrorsine, were grown on $5 \mathrm{mM}$ retrorsine during 10 days. Hol (2003) found that after these 10 days of pre-culturing fungi on water agar containing retrorsine, Pestalotiopsis sp. was significantly less sensitive to the PAs retrorsine and integerrimine, while Rhizoctonia sp. and Broomella acuta showed the same sensitivity to PAs as after pre-culturing on water agar alone. Hol (2003) suggested that the increased performance of Pestalotiopsis sp. was probably a phenotypic change. Apparently rapid phenotypic adaptation does occur. When it is this easy for fungi to adapt to PAs, we might question whether PAs are effective as antifungal defence. Tolerance to PAs was shown to be species specific and a variation was shown in PA activities. The fact that some fungi were tolerant or even stimulated by PAs does not deny the antifungal activity of PAs against other fungi. Antifungal effect of major PAs such as senecionine, seneciphylline, erucifoline and jacobine in the roots of PA-producing plants still haven't been tested.

There are also other microorganisms in an entire different biotope that are able to cope with PAs. Ruminal bacteria living in the stomach of some mammals can transform PAs before absorption into the body of the host may occur (Lanicang 1970). This may result in detoxification of the ingested PAs, which may be life saving for the host mammals. It is well known that PA-containing plants cause extensive livestock losses all over the world (Craig et al. 1991). When parts of these plants are ingested in substantial quantities, PAs can cause acute and chronic liver damage in large mammals including humans (Mattocks 1986). Sheep and goats are relatively resistant to the toxic effects of PAs thanks to bacterial decomposition of PAs in their stomach (Cheeke 1988; Stegelmeier et al. 1999). The microorganisms that detoxify PAs have not yet been identified but Wachenheim et al. (1992) found that jacobine biotransformation involves multiple bacterial species and they suggested that gram-positive bacteria play a key role. The PA biotransformation was inhibited when ruminal antibiotics, especially against gram-positive bacteria, where used. These results might be very helpful for the identification and isolation of PA-transforming bacteria and can be applied to induce and enhance resistance to PAs in mammals (Lodge-Ivey et al. 2005).

From the few studies that exist we can conclude that there are indications that adaptation of microorganisms to PAs occur. However, the evolutionary ecological consequences of this remains unclear. More research needs to be done to get a better insight on the adaptation mechanisms and strategies by microorganisms.

\section{Ecological effects on pathogens; aboveground}

Aboveground pathogens like rusts are common parasites of many plants among which PA-producing Asteraceae. Puccinia dioicae, for instance, is a common rust species on J. vulgaris (Harper and Wood 1957) and Puccinia lagenophorae is common on S. vulgaris (Paul and Ayres 1986a, b). S. vulgaris plants infected by $P$. lagenophorae are strongly hampered in their growth and reproduction. Reproduction was negatively influenced by rust infection because fewer plants flowered and per plant fewer buds, mature capitula and seeds were produced (Paul and Ayres 1986a, b). Studies on the effects of PAs on aboveground pathogens are very scarce. Infection of $S$. vulgaris by $P$. lagenophorae was enhanced at highnutrient conditions (Tinney et al. 1998). This could have a relation with the PA production in the plant. 
Hol et al. (2003) found that high-nutrient conditions decreased the PA concentrations in J. vulgaris. This may imply that the increased mycelium growth of pathogenic fungi such as $P$. lagenophorae may be related to lowering of the PA concentration in the host at higher nutrient concentrations. However in contrast with this suggestion, $P$. dioicae was found to cause most damage on J. vulgaris plant containing high PA levels including the alkaloid jacobine. The relationship between PA-producing plants and their aboveground pathogens in the field need further investigation before any conclusions can be drawn on their relation with PAs.

\section{Ecological effects on pathogens; belowground}

Perennial plant species contain high food reserves in the roots for vegetative reproduction and re-growth. Also, this helps plants to tolerate aboveground herbivory such as complete defoliation by specialists like T. jacobaeae on J. vulgaris (van der Meijden et al. 1988, 2001). The roots of these plant species are used for production and storage of PAs (Hartmann and Ober 2000). The concentration of PAs in the root crown of fully grown $J$. vulgaris plants in the field can be up to $4 \mathrm{mg} / \mathrm{g}$ dry weight (Kowalchuk et al. 2006). Thus, one could expect that these roots may strongly be protected against attackers.

The tissue in which plant defence compounds are stored is often crucial for their effectiveness. Hol et al. (2003) studied the distribution of PAs over different root parts. They observed that the concentration in the main root cortex was five times higher than the concentrations in the vascular cylinder. This suggests that a first line of defence against microbial attackers from the outside world may be created by tissue containing the highest concentration of PAs. The mature root parts are probably well protected because of its importance for re-growth after damage. Therefore from an evolutionary point of view it is reasonable that they contained the highest PA concentrations.

Recent observations point to certain clues on what type of PAs in J. vulgaris act as key players in root protection (Hol et al. 2003, 2004; Kowalchuk et al. 2006). When the roots or shoots of this species were damaged, jacobine and seneciphylline levels increased in the roots (Hol et al. 2004). This suggests that these PAs are important for root protection when the plant is under attack belowground. Hol et al. (2003) also found that an increase of nutrients in the soil decreased the PA concentrations in $J$. vulgaris probably due to a dilution effect. The biomass of the plant increased when nutrient levels rose mainly due to increases in the aboveground biomass, whereas the belowground plant biomass did not change significantly. Since the PA production is closely linked to root growth (Frischknecht et al. 2001) the total plant PA amount remained constant, therefore the concentration decreased as the total plant biomass increased. The concentrations of all PAs decreased with one exception. The concentration of jacobine remained constant in the shoots and increased in the roots when the total plant biomass increased. This emphasises the potential importance of jacobine for the defence of the plant (Hol et al. 2003). A field study on the role of root PAs in relation to fungi present in the rhizosphere of $J$. vulgaris pointed in the same direction. High-PA plants (1.13-3.92 mg/g dw) with jacobine as the major root PA suppressed the development of microorganisms by inducing a lower diversity of fungi in the rhizosphere compared to low-PA plants $(0-0.53 \mathrm{mg} / \mathrm{g} \mathrm{dw})$ or high-PA plants lacking jacobine in the root (Kowalchuk et al. 2006).

The presence of defence compounds such as PAs plays a role in the selection processes that shape the soil-borne microbial community present in the rhizosphere as shown in the above described study by Kowalchuk et al. (2006). This selection might favour those microorganisms that are tolerant or resistant to these defence compounds or in some cases even can degrade or utilize them. As described above, the highest PA concentrations in the roots were found in root cortex and the lateral roots instead of the vascular cylinder (Hol et al. 2003). Thus, we may expect that at least by root damage and sloughed of root cells PAs leak into the rhizosphere. Plants may also actively secrete PAs into the soil but, to our knowledge, this has never been tested also the exact PA levels in the rhizosphere have never been measured. The exact role that defence compounds play in plant protection against root-infecting bacteria and fungi is still not fully understood. Measuring low levels of chemical compounds that occur in the rhizosphere of the plant is still a challenge study area because of inadequate methods for analyses (Bais et al. 2006). 


\section{PA induction by microorganisms}

Many studies on the diversity and effectiveness of PAs as defence compounds have been performed with J. vulgaris and S. vulgaris of the Asteraceae family, especially in relation to insects. The concentration and composition of PAs in plant species is genotype dependent but also affected by the environment (Vrieling et al. 1993; Hol et al. 2003; Macel et al. 2004; Hol et al. 2004; Macel and Klinkhamer 2010; Joosten et al. 2009). Less is known about PA induction by pathogens aboveground. Tinney et al. (1998) found no significant effect of P. lagenophorae on the total PA concentration of $S$. vulgaris and hardly any effect on the PA composition, although infection caused a reduction in growth. The root dry weight of the infected plants was significantly lower compared to the uninfected control plants, while no significant difference was found for the vegetative tissue aboveground. We would expect that the PA concentration in the infected plants should be lower since PA production is closely linked to root growth (Hol et al. 2003). When focussing on particular plant parts instead of the whole plant, a significantly lower PA concentration in the rust infected plants were found in capitula and roots compared to the uninfected plants but not in the vegetative tissue which contained $90 \%$ of the total PA concentration. Although the rust infection caused reduction in growth for S. vulgaris, it had little influence on the overall PA concentration. PA synthesis was not induced by the aboveground rust infection but changes in PA distribution could be one of the effects (Tinney et al. 1998). This result is consistent with the conclusions from a study on Cynoglossum officinale (van Dam and Vrieling 1994), where mechanical wounding in leaves did not induce PA synthesis.

Bezemer et al. (2006) found that aboveground herbivory was related to the fungal community belowground. They suggested that the fungal community directly (Joosten et al. 2009) or indirectly (Hol et al. 2003) changed the concentration of different PAs in the shoots and in this way affected the aboveground insect community. However the PA concentrations were not measured. Macel and Klinkhamer (2010) noticed that the composition of PAs in genotypes of $J$. vulgaris changed in the field compared to the initial composition in laboratory clones. The PA composition also differed between the aboveground parts of clones grown on two different experimental field sites. Low nutrient levels in soil (Hol et al. 2003) and root damage (Hol et al. 2004) has been shown to result in an increased PA concentration in the shoots of J. vulgaris. Joosten et al. (2009) found a strong effect of soil-type and soil-borne microorganisms on the composition of PAs in roots and shoots of this plant species. Clonal plants of two genotypes were grown on two sterilized soil and sterilized soils inoculated with with $5 \%$ of non-sterilized soil of either of the two soil-types. Statistically, the first two discriminant functions classified around $80 \%$ of all the combinations of soil-types and inoculation treatments correctly based on the PA expression in roots and shoots of both genotypes. In particular the levels of retrorsine and retrorsine $N$-oxide were case specific in response to specific soil inoculation. In the study of Hol and van Veen (2002), retrorsine and retrorsine $\mathrm{N}$-oxide had inhibitory effects on mycelium growth of several plant-associated fungi. The levels of jacobine and jacobine $\mathrm{N}$-oxide were raised in the shoots of plants grown on specific soils. This influence of soiltype and soil-borne microorganisms could have major ecological consequences as changes in the concentration of individual PAs aboveground may attract specialist herbivores while deterring generalists (McEvoy et al. 1993; Macel and Vrieling 2003; Macel et al. 2005; Macel and Klinkhamer 2010). It could also have considerable consequences for other relevant processes for instance for the success of invasive plants and for the biological control of plants.

\section{Conclusions}

The existing evidence on the role PAs play in plant defence against microorganisms is scarce especially in comparison to ecological studies on insects. However, the studies that are available do suggest a potential role of PA in the plant's defence strategy against microorganisms. Unfortunately hardly any field studies are performed on this topic, which is remarkable, given the results of the in vivo experiments. In vitro experiments show potential effects of plant-produced PAs on microorganisms. This idea is supported by in vivo experiments, although in limited numbers. PA mixtures affect microorganisms in vivo and in vitro and variation exists in anti-microbial effects of different 
PAs (Hol et al. 2003). Several PAs tested showed structurally related PAs differ in their effects on microorganisms but some PAs were more effective than others. High levels of jacobine were associated with lower fungal diversity in the rhizosphere of the plant of its precursor, but the primary PA senecionine, did not have this effect (Kowalchuk et al. 2006). There are indications that adaptation of microorganisms to PAs occur, in particular microorganisms that were isolated from PA-containing plants showed a higher tolerance and more rapid adaptation (Hol 2003). The relationship between PAs and microorganisms need further investigation before the strength of microorganisms as selection factor can fully be assessed.

Open Access This article is distributed under the terms of the Creative Commons Attribution Noncommercial License which permits any noncommercial use, distribution, and reproduction in any medium, provided the original author(s) and source are credited.

\section{References}

Atta-ur-Rahman, Choudhary MI, Majeed A, Shabbir M, Ghani U, Shameel M (1997) A succinylanthranilic acid ester and other bioactive constituents of Jolyna laminarioides. Phytochemistry 46:1215-1218

Bais HP, Weir TL, Perry LG, Gilroy S, Vivanco JM (2006) The role of root exudates in rhizosphere interactions with plants and other organisms. Annu Rev Plant Biol 57:233-266

Bezemer TM, Harvey JA, Kowalchuk GA, Korpershoek H, van der Putten WH (2006) Interplay between Senecio jacobaea and plant, soil, and aboveground insect community composition. Ecology 87:2002-2013

Boppré M (1986) Insect pharmacophagously utilizing defensive plant chemicals (pyrrolizidine alkaloids). Naturwissenschaften 73:17-26

Cheeke PR (1988) Toxicity and metabolism of pyrrolizidine alkaloids. J Anim Sci 66:2343-2350

Craig AM, Pearson EG, Meyer C, Schmitz JA (1991) Serum liver enzyme and histopathologic changes in calves with chronic and chronic-delayed Senecio jacobaea toxicosis. Am J Vet Res 52:1969-1978

Ehrlich PR, Raven PH (1964) Butterflies and plants: a study in coevolution. Evolution 18:586-608

Erdemoglu N, Ozkan S, Tosun F (2007) Alkaloid profile and antimicrobial activity of Lupinus angustifolius L. alkaloid extract. Phytochem Rev 6:197-201

Erdemoglu N, Ozkan S, Duran A, Tosun F (2009) GC-MS analysis and antimicrobial activity of alkaloid extract from Genista vuralii. Pharm Biol 47:81-85

Frischknecht PM, Schuhmacher K, Müller-Schärer H, Baumann TW (2001) Phenotypic plasticity of Senecio vulgaris from contrasting habitat types: growth and pyrrolizidine alkaloid formation. J Chem Eco 27:343-358
Harborne JB (2003) Introduction to ecological biochemistry. Academic Press, London

Harper JL, Wood WA (1957) Biological flora of the British Isles, Senecio jacobaea L. J Ecol 45:617-637

Hartmann T (1999) Chemical ecology of pyrrolizidine alkaloids. Planta 207:483-495

Hartmann T, Dierich B (1998) Chemical diversity and variation of pyrrolizidine alkaloids of the senecionine type: biological need or coincidence? Planta 206:443-451

Hartmann T, Ober D (2000) Biosynthesis and metabolism of pyrrolizidine alkaloids in plants and specialized insect herbivores. In: Leeper FJ, Vederas JC (eds) Topics in current chemistry, vol 209. Springer, Berlin, p 207

Hartmann T, Toppel G (1987) Senecionine $N$-oxide, the primary product of pyrrolizidine alkaloid biosynthesis in root cultures of Senecio vulgaris. Phytochemistry 26:16391643

Hartmann T, Witte L (1995) Pyrrolizidine alkaloids: chemical, biological and chemoecological aspects. In: Pelletier SW (ed) Alkaloids: chemical and biological perspectives, vol 9. Pergamon Press, Oxford, p 155

Hol WHG (2003) Role of pyrrolizidine alkaloids in the defense against fungi. $\mathrm{PhD}$ thesis, Leiden University, Leiden, The Netherlands

Hol WHG, van Veen JA (2002) Pyrrolizidine alkaloids from Senecio jacobaea affect fungal growth. J Chem Ecol 28:1763-1772

Hol WHG, Vrieling K, van Veen JA (2003) Nutrients decrease pyrrolizidine alkaloid concentrations in Senecio jacobaea. New Phytol 158:175-181

Hol WHG, Macel M, van Veen JA, van der Meijden E (2004) Root damage and aboveground herbivory change concentration and composition of pyrrolizidine alkaloids of Senecio jacobaea. Basic Appl Ecol 5:253-260

Jain S, Sharma R (1987) Antimicrobial activity of pyrrolizidine alkaloids from Heliotropium ellipticum. Chem Pharm Bull 55:3487-3489

Joosten L, Mulder PPJ, Klinkhamer PGL, van Veen JA (2009) Soil-borne microorganisms and soil-type affect pyrrolizidine alkaloids in Jacobaea vulgaris. Plant Soil 325: 133-143

Kowalchuk GA, Hol WHG, van Veen JA (2006) Rhizosphere fungal communities are influenced by Senecio jacobaea pyrrolizidine alkaloid content and composition. Soil Biol Biochem 38:2852-2859

Krischik VA, Goth RW, Barbosa P (1991) Generalized plant defense: effects on multiple species. Oecologia 85 : 562-571

Lanicang W (1970) Metabolism of pyrrolizidine alkaloids in the ovine rumen. 11. Some factors affecting rate of alkaloid breakdown by rumen fluid in vitro. Aust $\mathbf{J}$ Agric Res 21:633-639

Lindigkeit R, Biller A, Buch M, Schiebel HM, Boppre M, Hartmann T (1997) The two faces of pyrrolizidine alkaloids: the role of the tertiary amine and its $\mathrm{N}$-oxide in chemical defense of insects with acquired plant alkaloids. Eur J Biochem 245:626-636

Lodge-Ivey SL, Rappe MS, Johnston WH, Bohlken RE, Craig AM (2005) Molecular analysis of a consortium of ruminal microbes that detoxify pyrrolizidine alkaloids. Can J Microbiol 51:455-465 
Ma WG, Fukushi Y, Tahara S (1999) Fungitoxic alkaloids from Hokkaido Corydalis species. Fitoterapia 70:258-265

Macel M, Klinkhamer PGL (2010) Chemotype of Senecio jacobaea affects damage by pathogens and insect herbivores in the field. Evol Ecol 24:237-250

Macel M, Vrieling K (2003) Pyrrolizidine alkaloids as oviposition stimulants for the cinnabar moth, Tyria jacobaeae. J Chem Ecol 29:1435-1446

Macel M, Vrieling K, Klinkhamer PGL (2004) Variation in pyrrolizidine alkaloid patterns of Senecio jacobaea. Phytochemistry 65:865-873

Macel M, Bruinsma M, Dijkstra SM, Ooijendijk T, Niemeyer HM, Klinkhamer PGL (2005) Differences in effects of pyrrolizidine alkaloids on five generalist insect herbivore species. J Chem Ecol 31:1493-1508

Marquina G, Laguna A, Franco P, Fernandez L, Perez P, Valiente O (1989) Antimicrobial activity of pyrrolizidine alkaloids from Heliotropium bursiferum Wr ex Grisebach. Pharmazie 44:870-871

Mattocks AR (1986) Chemistry and toxicology of pyrrolizidine alkaloids. Academic Press, London

McEvoy PB, Rudd NT, Cox CS, Huso M (1993) Disturbance, competition, and herbivory effects on ragwort Senecio jacobaea populations. Ecol Mono 63:55-75

McGonigle TP, Hyakumachi M (2001) Feeding on plant pathogenic fungi by invertebrates: comparison with saprotrophic and mycorrhizal systems. In: Jeger MJ, Spence NJ (eds) Biotic interactions in plant-pathogen associations. CABI Publishing, Wallingford, p 63

Morrissey JP, Osbourn AE (1999) Fungal resistance to plant antibiotics as a mechanism of pathogenesis. Microbiol Mol Biol Revs 63:708-724

Ober D (2003) Chemical ecology of alkaloids exemplified with the pyrrolizidines. In: Romeo JT (ed) Integrative phytochemistry: from ethnobotany to molecular ecology, vol 37. Pergamon, Amsterdam, pp 203-230

Osbourn AE (1996) Pre-formed antimicrobial compounds and plant defence against fungal attack. Plant Cell 8:1821-1831

Paul ND, Ayres PG (1986a) The impact of a pathogen (Puccinia lagenophorae) on populations of groundsel (Senecio vulgaris) over wintering in the field. I. Mortality, vegetative growth and the development of size hierarchies. J Ecol 74:1069-1084

Paul ND, Ayres PG (1986b) The impact of a pathogen (Puccinia lagenophorae) on populations of groundsel (Senecio vulgaris) overwintering in the field. II. Reproduction. J Ecol 74:1085-1094

Reina M, Mericli A, Cabrera R, Gonzalez-Coloma A (1995) Pyrrolizidine alkaloids from Heliotropium bovei. Phytochemistry 38:355-358

Reina M, Gonzalez-Coloma A, Gutierrez C, Cabrera R, Henriquez J, Villarroel L (1997) Bioactive saturated pyrrolizidine alkaloids from Heliotropium floridum. Phytochemistry 46:845-853

Reina M, Gonzalez-Coloma A, Gutierrez C, Cabrera R, Henriquez J, Villarroel L (1998) Pyrrolizidine alkaloids from Heliotropium megalanthum. J Nat Prod 61:1418-1420
Singh B, Sahu PM, Singh S (2002) Antimicrobial activity of pyrrolizidine alkaloids from Heliotropium subulatum. Fitoterapia 73:153-155

Soby S, Caldera S, Bates R, van Etten H (1996) Detoxification of the phytoalexins maackiain and medicarpin by fungal pathogens of alfalfa. Phytochemistry 41:759-765

Srivastava BP, Singh KP, Singh UP, Pandey VB (1994) Effect of some naturally occurring alkaloids on conidial germination of Botrytis cinerea. Bioved 5:69-72

Stegelmeier BL, Edgar JA, Colegate SM, Gardner DR, Scloch TK, Coulombe RA, Molyneux RJ (1999) Pyrrolizidine alkaloid plants, metabolism and toxicity. J Nat Toxins 8:95-116

Tinney G, Theuring C, Paul N, Hartmann T (1998) Effects of rust infection with Puccinia lagenophora on pyrrolizidine alkaloids in Senecio vulgaris. Phytochemistry 49:15891592

Van Dam NM, Vrieling K (1994) Genetic variation in constitutive and inducible pyrrolizidine alkaloid levels in Cynoglossum officinale L. Oecologia 99:374-378

Van Dam NM, Vuister LWM, Bergshoeff C, de Vos H, van der Meijden ED (1995) The 'raison d'etre' of pyrrolizidine alkaloids in Cynoglossum officinale: deterrent effects against generalist herbivores. J Chem Ecol 21:507-523

Van der Meijden E, Wijn H, Verkaar J (1988) Defence and regrowth, alternative plant strategies in the struggle against herbivores. Oikos 51:355-363

Van der Meijden E, de Boer NJ, van der Veen-van Wijk CAM (2001) Pattern of storage and regrowth in ragworth. Evol Ecol 14:439-455

Vrieling K, de Vos H, van Wijk CAM (1993) Genetic analysis of the concentrations of pyrrolizidine alkaloids in Senecio jacobaea. Phytochemistry 32:1141-1144

Wachenheim DE, Blythe LL, Craig AM (1992) Characterization of rumen bacterial pyrrolizidine alkaloid biotransformation in ruminants of various species. Vet Hum Toxicol 34:513

Werner C, Petrini O, Hesse M (1997) Degradation of the polyamine alkaloid aphelandrine by endophytic fungi isolated from Aphelandra tetragona. FEMS Microbiol Lett 155:147-153

Wink M (1988) Plant breeding: importance of plant secondary metabolites for protection against pathogens and herbivores. Theor Appl Genetics 75:225-233

Wippich C, Wink M (1985) Biological properties of alkaloids. Influence of quinolizidine alkaloids and gramine on the germination and development of powdery mildew, Erysiphe graminist f.sp.hordei. Experientia 41:1477-1479

Zhao W, Wolfender JL, Hostettmann K, Xu R, Qin G (1998) Antifungal alkaloids and limonoid derivatives from Dictamnus dasycarpus. Phytochemistry 47:7-11

Zhou CX, Liu JY, Ye WC, Liu CH, Tan RX (2003) Neoverataline $\mathrm{A}$ and $\mathrm{B}$ two antifungal alkaloids with a novel carbon skeleton from Veratrum taliense. Tetrahedron 59:5743-5747 